\author{
Adrian NOSOL ${ }^{1}$ \\ Marian BARTOSZUK ${ }^{2}$ \\ Przemysław WINIARSKI ${ }^{3}$
}

\title{
BADANIA ENERGOCHŁONNOŚCI PROCESU TOCZENIA
}

\begin{abstract}
W obecnej dobie energochłonność procesu wytwarzania często jest czynnikiem decydującym o pozycji wytwórcy na rynku. Konsumpcja energii jest w dużym stopniu uzależniona od parku maszynowego wytwórcy. Dąży się zatem do poszukiwania innowacyjnych strategii obróbki zmniejszających energochłonność wytwarzania. Niniejszy artykuł jest poświęcony analizie energochłonności przykładowego procesu toczenia. Rozważaniom poddano konsumpcję energii biernej w odniesieniu do całkowitej energii pobieranej z sieci dla procesu toczenia narzędziami konwencjonalnymi. Wykazano, że istnieje możliwość minimalizowania strat związanych z produkcją energii biernej przez umiejętny dobór narzędzi skrawających oraz stosowanie nowych strategii obróbki.
\end{abstract}

Słowa kluczowe: energochłonność, moc bierna, moc czynna, toczenie

\section{Wprowadzenie}

Współcześnie ze względów ekonomicznych i ekologicznych przemysł maszynowy dąży do zmniejszenia zużycia energii podczas realizacji procesów produkcyjnych [6]. Trzeba zaznaczyć, że znaczący udział w tych kosztach ma koszt energii elektrycznej. W związku z tym przemysł szuka oszczędności w tym zakresie przez zakup energooszczędnych obrabiarek oraz stosowanie nowych energooszczędnych strategii obróbki [4].

Bardzo często przedsiębiorstwa, nie mając dostatecznej wiedzy o ilości i rodzaju pobieranej przez siebie energii, płacą wysokie rachunki. Co więcej, w wielu przypadkach zakład energetyczny nalicza karne opłaty za nadmierną konsumpcję mocy biernej. Nie każdego przedsiębiorcę stać na zainstalowanie systemu do kompensacji energii biernej. Zazwyczaj są to drogie urządzenia, opłacalne tylko w przypadku dużych zakładów produkcyjnych [7-9]. W świetle przedstawionych informacji wiedza o pobieranej z sieci energii oraz umiejętne gospodarowanie

\footnotetext{
1 Autor do korespondencji/corresponding author: Adrian Nosol, Politechnika Opolska, 45-272 Opole, ul. Sosnkowskiego 31, tel.: +48 774498672, e-mail: a.nosol@po.opole.pl

${ }^{2}$ Marian Bartoszuk, Politechnika Opolska, e-mail: m.bartoszuk@po.opole.pl

${ }^{3}$ Przemysław Winiarski, Politechnika Opolska, e-mail: winiarski.przemyslaw@gmail.com
} 
konsumpcją energii mogą się przyczyniać do konkretnych korzyści ekonomicznych.

Maszyny technologiczne są najczęściej zasilane układami wielofazowymi. $\mathrm{Z}$ tego względu, badając sumaryczną moc pobieraną przez obrabiarkę w czasie procesu, należy zwrócić szczególną uwagę na jej składowe, czyli moc czynną i bierną $[2,3,5,9]$. Moc czynna jest średnią wartością mocy chwilowej i jest niezbędna do wykonywania pracy przez maszynę. Opisuje się ją za pomocą wzoru [8]:

$$
P=U \times I \times \cos \varphi
$$

gdzie: $U$ - napięcie,

$I$ - natężenie,

$\Phi$ - kąt przesunięcia fazowego.

Z kolei moc bierna nie jest bezpośrednio wykorzystywana przez maszynę, jest jednak pobierana z sieci. Wyraża się ją wzorem [8]:

$$
Q=U \times I \times \sin \varphi
$$

gdzie: $U$ - napięcie,

$I$ - natężenie,

$\Phi$ - kąt przesunięcia fazowego.

Moc pozorna stanowi iloczyn wartości skutecznej napięcia i natężenia. Wyraża się ją wzorem [8]:

$$
S=U \times I
$$

gdzie: $U$ - napięcie,

$I$ - natężenie.

Ze względu na fakt, że krajowy przemysł części maszyn wciąż posiada maszyny konwencjonalne, autorzy niniejszego artykułu postanowili przeanalizować przypadek toczenia na tokarce konwencjonalnej.

\section{Metodyka badań}

Do badań przyjęto zatem przypadek toczenia konwencjonalnego narzędziem PTGNR 2020-16 wyposażonym w ostrza o różnej konfiguracji łamacza wiórów. Narzędzia użyte w badaniach pokazano w tab. 1. Badania zrealizowano na tokarce konwencjonalnej TUM-35D1 ze zmodernizowanym układem napędowym, zapewniającym elastyczną regulację prędkości skrawania. Stanowisko badawcze przedstawiono na rys. 1 . 
Tabela 1. Zestawienie ostrzy użytych w badaniach

Table 1. The list of cutting inserts used in the tests

\begin{tabular}{|c|c|c|}
\hline Symbol & Materiał & Fot. \\
\hline TNMA 160408 & GC3205 \\
\hline TNMG 160404-PC & GC4225 \\
\hline TNMG 160408 & GC4235 \\
\hline TNMG 160408R-K & GC1525 \\
\hline
\end{tabular}

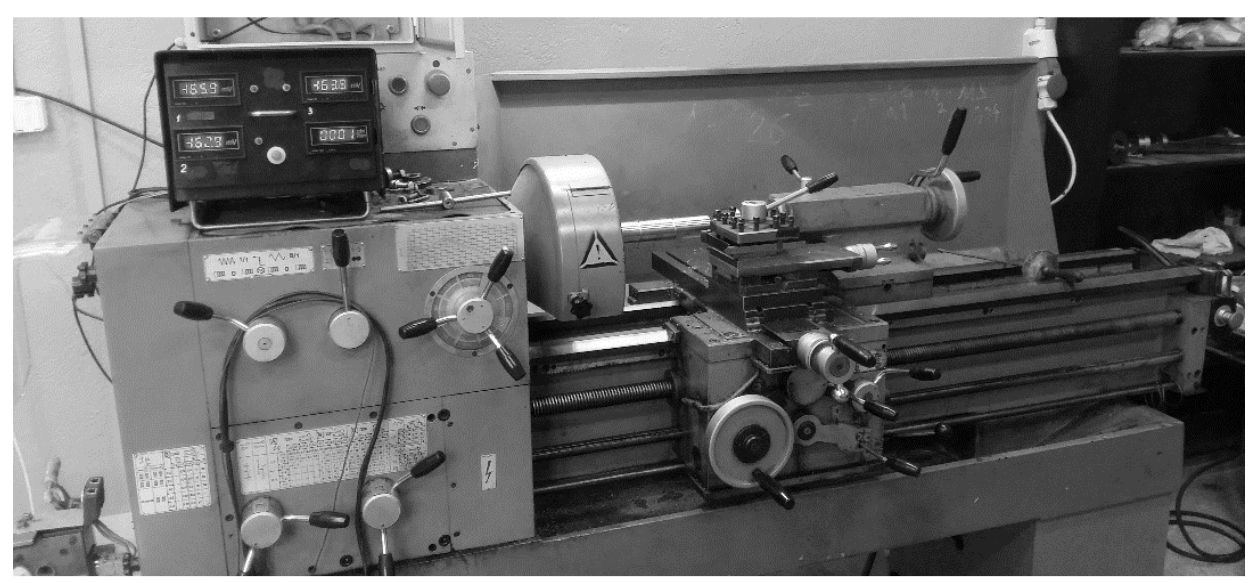

Rys. 1. Stanowisko badawcze

Fig. 1. Research stand

Pomiarów konsumpcji energii dokonywano z użyciem przyrządu UT233 firmy UNI-T. W trakcie badań zbierano informacje o napięciu sieci zasilającej $U$, poborze prądu $I$ przez maszynę i o wartości przesunięcia fazowego $\cos \varphi$. Wartość mocy pozornej $S$, czynnej $P$ i biernej $Q$ wyznaczano z obliczeń, zgodnie ze wzorami (1)-(3).

Jako materiał obrabiany wybrano stal węglową konstrukcyjną AISI 1045 normalizowaną. Próbka była podzielona na sekcje w taki sposób, aby umożliwić wykonanie trzech pomiarów dla jednych ustawień maszyny. W badaniach przy- 
jęto stałą prędkość skrawania $v_{c}=170 \mathrm{~m} / \mathrm{min}$ oraz głębokość skrawania $a_{p}=0,5$ $\mathrm{mm}$. Posuw był zmienny skokowo i wynosił odpowiednio: 0,$04 ; 0,10 ; 0,16 ; 0,20$; 0,$28 ; 0,40 \mathrm{~mm} / \mathrm{obr}$. W badaniach zbierano również informacje o chropowatości powierzchni obrobionej, ze szczególnym uwzględnieniem parametrów $R_{a}$ i $R_{t}$.

\section{Wyniki badań $i$ ich analiza}

Na podstawie badań otrzymano wyniki dla różnych ostrzy, ale dla parametrów obróbki zmiennych w tym samym zakresie. Przykładowe wyniki badań zamieszczono w tabelach. $\mathrm{W}$ tabeli 2 przedstawiono wyniki dla ostrza TNMA 160408, natomiast w tab. 3 - dla ostrza TNMG 160404-PC.

Tabela 2. Wyniki prób eksperymentalnych uzyskane dla ostrza TNMA 160408

Table 2. Experimental results obtained for the TNMA 160408 cutting insert

\begin{tabular}{|c|c|c|c|c|c|c|}
\hline \multicolumn{7}{|c|}{ TNMA 160408} \\
\hline$f[\mathrm{~mm} / \mathrm{obr}$ ] & $\begin{array}{c}\text { moc czynna } P \\
{[\mathrm{~W}]}\end{array}$ & $\begin{array}{c}\text { moc bierna } Q \\
{[\text { Var] }}\end{array}$ & $\begin{array}{c}\text { moc pozorna } S \\
{[\mathrm{VA}]}\end{array}$ & $Q / S[\%]$ & $R_{t}[\mu \mathrm{m}]$ & $R_{a}[\mu \mathrm{m}]$ \\
\hline 0,04 & 1542,6 & 61,2 & 1545,6 & 3,96 & 10,88 & 1,38 \\
\hline 0,10 & 1797,6 & 39,6 & 1798,6 & 2,20 & 9,94 & 1,26 \\
\hline 0,16 & 2076,6 & 49,8 & 2078,4 & 2,40 & 8,97 & 1,54 \\
\hline 0,20 & 2205,1 & 34,3 & 2205,9 & 1,56 & 11,62 & 2,52 \\
\hline 0,28 & 2481,9 & 4,3 & 2481,9 & 0,17 & 15,22 & 3,49 \\
\hline 0,40 & 2843,5 & 10,3 & 2843,5 & 0,36 & 26,35 & 5,90 \\
\hline
\end{tabular}

Tabela 3. Wyniki prób eksperymentalnych uzyskane dla ostrza TNMG 160404-PC

Table 3. Experimental results obtained for the TNMG 160404-PC cutting insert

\begin{tabular}{|c|c|c|c|c|c|c|}
\hline \multicolumn{7}{|c|}{ TNMG 160404-PC } \\
\hline$f$ [mm/obr. $]$ & $\begin{array}{c}\text { moc czynna } P \\
{[\mathrm{~W}]}\end{array}$ & $\begin{array}{c}\text { moc bierna } Q \\
{[\text { Var] }}\end{array}$ & $\begin{array}{c}\text { moc pozorna } S \\
{[\mathrm{VA}]}\end{array}$ & $Q / S[\%]$ & $R_{t}[\mu \mathrm{m}]$ & $R_{a}[\mu \mathrm{m}]$ \\
\hline 0,04 & 1269,1 & 75,9 & 1274,0 & 5,96 & 6,01 & 0,88 \\
\hline 0,10 & 1480,9 & 103,2 & 1487,1 & 6,94 & 10,13 & 1,33 \\
\hline 0,16 & 1617,1 & 44,5 & 1618,4 & 2,75 & 9,03 & 1,34 \\
\hline 0,20 & 1819,6 & 46,0 & 1821,0 & 2,52 & 9,80 & 1,42 \\
\hline 0,28 & 2055,9 & 47,7 & 2057,1 & 2,32 & 12,39 & 2,46 \\
\hline 0,40 & 2362,1 & 32,4 & 2362,6 & 1,37 & 22,91 & 5,39 \\
\hline
\end{tabular}

Analiza wartości zebranych w tabelach wskazuje, że oczywiście konsumpcja mocy wzrasta wraz z intensyfikacją procesu skrawania, co jest równoznaczne ze wzrostem obciążenia napędu głównego tokarki. Analizując otrzymane wyniki w ujęciu graficznym (rys. 2), można stwierdzić, że intensywność wzrostu poboru mocy czynnej dla wszystkich badanych ostrzy jest bardzo podobna. Niewielkie zmiany przebiegu krzywej mocy, zaobserwowane dla posuwów mniejszych od 
0,2 mm/obr., pochodzą prawdopodobnie od zakłóceń spowodowanych przez mechanizmy obrabiarki. Należy jednak zauważyć, że dla ostrzy TNMG odnotowano wartości pobieranej z sieci mocy czynnej mniejsze o około $10 \%$ w całym badanym zakresie. Za przyczynę takiego obniżenia poboru mocy uważa się kształt powierzchni natarcia tych ostrzy. Obiektywnie można zatem stwierdzić, że umiejętny dobór stereometrii ostrza (łamacza wiórów) może prowadzić do zmniejszenia konsumpcji energii zużywanej na obróbkę skrawaniem.

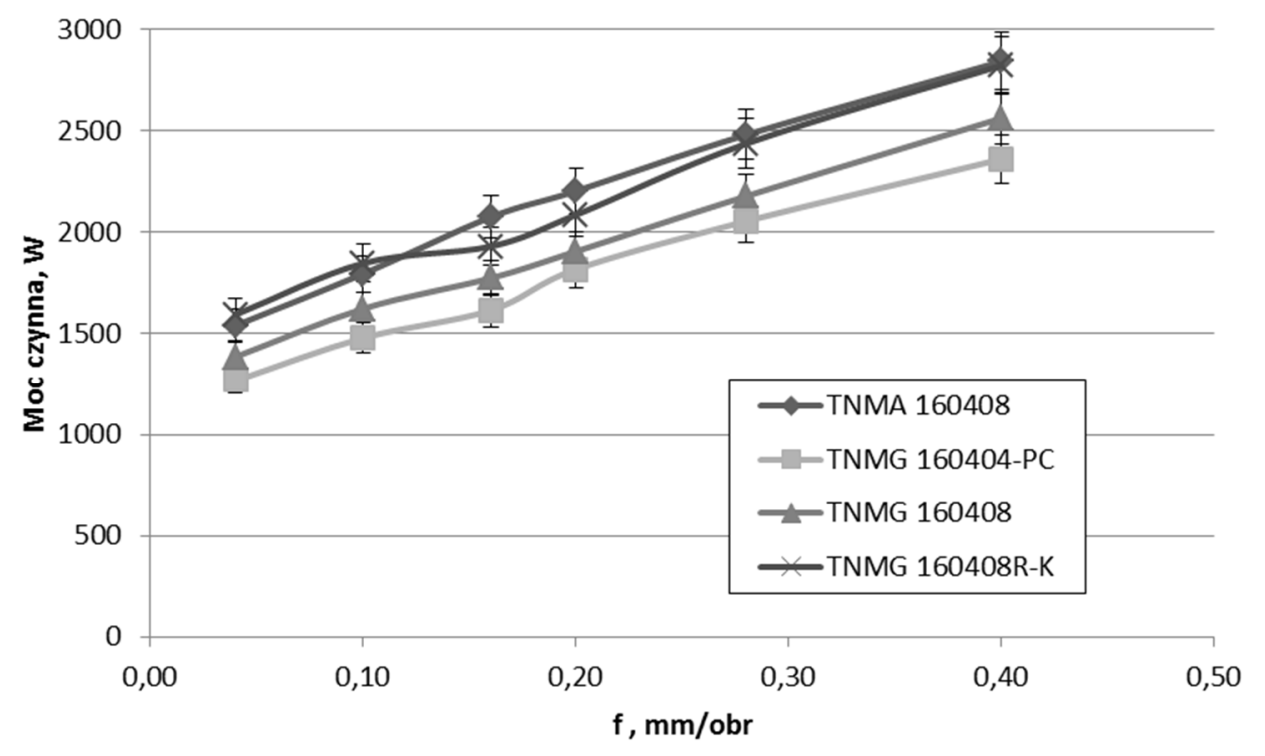

Rys. 2. Zależność poboru mocy czynnej od posuwu dla badanych ostrzy

Fig. 2. The effect of feed on active power consumption for the tested inserts

Analiza zmian mocy biernej pozwala zauważyć, że zwiększenie obciążenia maszyny przez zwiększenie parametrów obróbki skrawaniem powoduje wzrost konsumpcji energii pozornej przy jednoczesnym zmniejszeniu procentowego udziału energii biernej [1-3]. Zjawisko to zobrazowano graficznie na rys. 3. Zaznaczone na wykresie anomalie $w$ przebiegu mocy biernej wynikają prawdopodobnie z obserwowanych zmian parametrów sieci zasilającej oraz z zakłóceń wprowadzanych do sieci przez maszyny pracujące w pobliżu.

Analizując jakość powierzchni obrabianego elementu, zauważa się niższe wartości parametrów chropowatości $R_{t}$ i $R_{a}$ dla ostrza TNMG. Można zaobserwować, że wartość parametru $R_{t}$ ma podobną wartość przy toczeniu ostrzem TNMA $\mathrm{z}$ posuwem $0,1 \mathrm{~mm} / \mathrm{obr}$. oraz przy toczeniu ostrzem TMNG z posuwem 0,2 $\mathrm{mm} /$ obr. Inaczej rzecz ujmując - chcąc uzyskać wartość parametru $R_{t}$ zbliżoną do $10 \mu \mathrm{m}$, można zastosować ostrze TNMG z wartością posuwu większą o $100 \%$ niż w przypadku ostrza TNMA. Powoduje to nieznaczne zwiększenie poboru mocy 


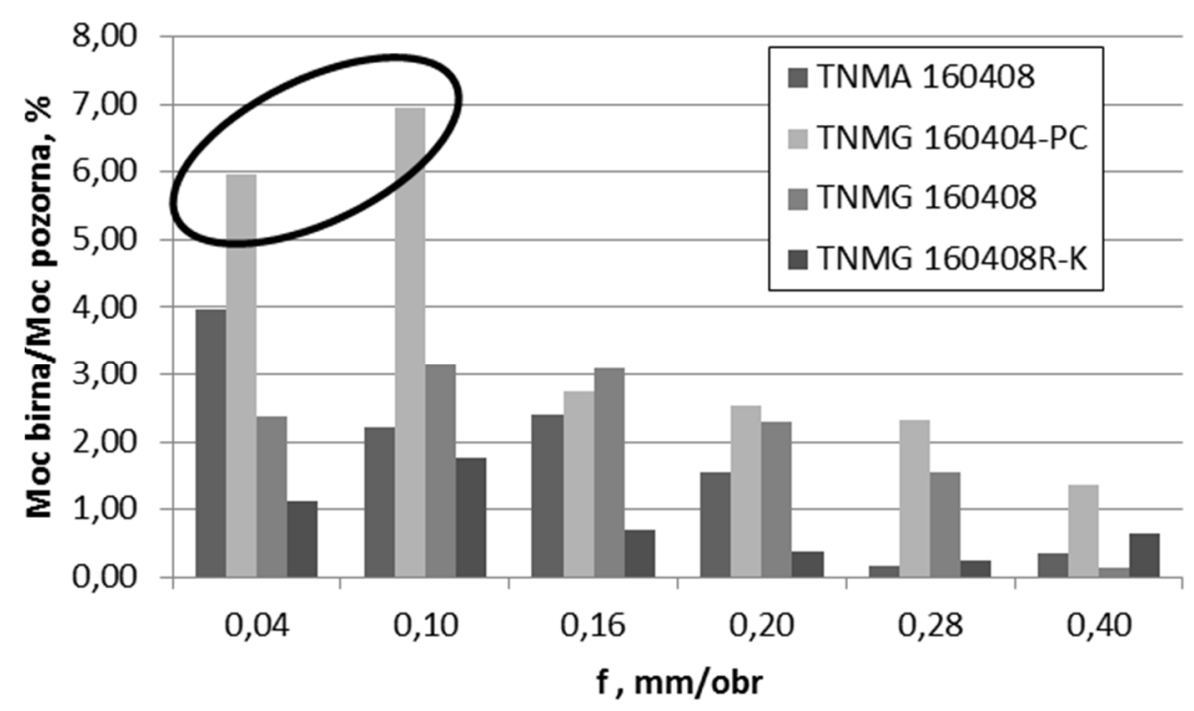

Rys. 3. Stosunek mocy biernej do mocy pozornej przy zmiennych wartościach posuwu

Fig. 3. The ratio of passive power to apparent power for variable feed rates

pozornej (bo tylko o ok. 1-2\%), przy jednoczesnym skróceniu czasu obróbki o połowę. W konsekwencji zmniejsza się energochłonność całego procesu. Zdaniem autorów przyczyny różnic w wartościach zmierzonych parametrów chropowatości trzeba upatrywać w różnej stereometrii badanych ostrzy skrawających. $\mathrm{W}$ niniejszych badaniach nie wyznaczano rzeczywistej stereometrii ostrzy. Do analiz założono wszystkie wymiary ostrzy na podstawie danych producenta narzędzi. Przytoczone informacje skłaniają do wniosku, że celowe wydaje się prowadzenie procesu skrawania przy możliwie wysokich wartościach parametrów obróbkowych. W ten sposób więcej energii (w ujęciu procentowym) pożytkuje się na sam proces skrawania. Z kolei udział energii biernej - niekorzystnej z punktu widzenia odbiorcy, jest pomniejszony $[8,10]$. Zjawisko to jest szczególnie ważne, gdyż większość wytwórców części maszyn nie posiada urządzeń do kompensacji energii biernej. Jak wiadomo, każda maszyna indukcyjna wytwarza energię bierną, musi ją zatem przesyłać przez sieć. Przedstawione w niniejszym artykule wyniki wskazują na możliwość opracowania strategii obróbki pozwalającej na bardziej racjonalne wykorzystanie energii, bez konieczności inwestowania $\mathrm{w}$ drogie systemy kompensacji energii biernej.

\section{Podsumowanie}

Przeprowadzone badania i wyniki analizowane w ramach niniejszego artykułu stanowią jedynie część badań wstępnych związanych z analizą konsumpcji mocy w obróbce skrawaniem. Już na ich podstawie można stwierdzić, że kształt 
powierzchni natarcia ostrza w sposób istotny wpływa na konsumpcję energii elektrycznej. W konsekwencji możliwy jest dobór takiego narzędzia, przy którym będzie zachowana jakość powierzchni obrobionej i dokładność wymiarowa, a zmniejszeniu ulegnie energochłonność procesu. Co więcej, wzrost intensywności procesu skrawania powoduje oczywisty wzrost konsumpcji energii elektrycznej, jednak procentowy udział energii biernej maleje. Oznacza to bardziej ekonomiczne wykorzystanie pobieranej z sieci energii.

\section{Literatura}

[1] Barylski A.: Energochłonność docierania jednotarczowego elementów płaskich z węglików spiekanych oraz ceramiki technicznej, Mechanik, 89 (2016) 1358-1359.

[2] Chudy R., Grzesik W.: Badanie energochłonności toczenia i nagniatania stali utwardzonej, IX Szkoła Obróbki Skrawaniem, red. E. Miko, Mierzęcin 2015, ss. 408-414.

[3] Chudy R., Grzesik W.: Comparison of power and energy consumption for hard turning and burnishing operations of $41 \mathrm{Cr} 4$ steel, J. Machine Eng., 15 (2015) 113-120.

[4] Grzesik W.: Podstawy skrawania materiałów konstrukcyjnych, WNT, Warszawa 2010.

[5] Liu N., Zhang Y.F., Lu W.F.: A hybrid approach to energy consumption modelling based on cutting power: a milling case, J. Cleaner Production, 104 (2015) 264-272.

[6] Mori M., Fujishima, M., Inamasu, Y., Oda Y.: A study on energy efficiency improvement for machine tools, CIRP Annals - Manuf. Technol., 60 (2011) 145-148.

[7] Stembalski M.: Sposoby ograniczenia zużycia energii przez obrabiarki skrawające do metali, Inż. Ap. Chem., 49 (2010) 107-108.

[8] Strzelecki R., Supronowicz H.: Współczynnik mocy w systemach zasilania prądu przemiennego i metody jego poprawy, OW PW, Warszawa 2000.

[9] Terelak-Tymczyna A., Miądlicki K., Nowak. M.: Efektywność energetyczna procesu obróbki skrawaniem na przykładzie toczenia, Mechanik, 89 (2016) 1308$-1309$.

[10] Zhong Q., Tang R., Peng T.: Decision rules for energy consumption minimization during material removal process in turning, J. Cleaner Production, 140 (2017) 1819-1827 .

\section{A STUDY OF THE ENERGY CONSUMPTION OF THE TURNING PROCESS}

\section{S u m m a r y}

In the present day, the energy consumption of the manufacturing process is often the decisive factor for the manufacturer's position on the market. Energy consumption depends to a large extent on the manufacturer's machine stock. It is therefore industry sought to seek innovative machining strategies that reduce the energy intensity of production. This article is devoted to an analysis of the energy consumption of an exemplary turning process. Passive energy consumption was investigated 
for total energy drawn from the grid for the conventional tool turning process. It has been shown that there is the possibility of minimizing losses associated with the production of passive energy through the skillful selection of cutting tools and the application of new machining strategies.

Keywords: energy consumption, passive power, active power, turning

DOI: $10.7862 / \mathrm{rm} .2017 .49$

Przestano do redakcji: 14.08 .2017

Przyjęto do druku: 18.10.2017 